\author{
MALGORZATA PYCHNER \\ ORCID: 0000-0003-1353-4899 \\ Uniwersytet Marii Curie-Skłodowskiej w Lublinie \\ e-mail: malgorzata.pychner@gmail.com
}

\title{
Diagnoza potrzeb edukacyjnych w zakresie bezpieczeństwa osobistego w percepcji uczniów szkół podstawowych na przykładzie miasta powiatowego
}

\author{
https://doi.org/10.19195/2083-7763.10.18
}

\section{Abstrakt}

W niniejszym referacie zaprezentowano wyniki badań ankietowych mających na celu zidentyfikowanie potrzeb i oczekiwań uczniów szkół podstawowych i gimnazjów wobec edukacji dla bezpieczeństwa. Przystępując do realizacji badań, punktem wyjścia uczyniono stwierdzenie, że aby skutecznie oddziaływać na młodzież w zakresie bezpiecznych zachowań, należy dokonywać analizy zagrożeń charakterystycznych dla regionu, jak również diagnozować potrzeby samych odbiorców. Badaniami objęto grupę uczniów z trzech szkół znajdujących się na terenie Garwolina — jednego z miast powiatowych w województwie mazowieckim. Ich celem było zdefiniowanie oczekiwań edukacyjnych młodzieży w kwestii bezpieczeństwa personalnego ograniczonego do zagrożeń związanych z przestępczością i patologiami społecznymi, które mogą stanowić podstawę do implementacji wskazywanych przez respondentów kwestii w działania szkół i instytucji realizujących zadania na rzecz bezpieczeństwa w regionie.

Słowa kluczowe: edukacja dla bezpieczeństwa, młodzież, przestępczość, patologie społeczne

Bezpieczeństwo nie posiada jednej, jednolitej definicji ${ }^{1}$. Świadczy to o niezwykłej złożoności i wieloaspektowości tej dziedziny, którą należy rozpatrywać w zależności od przyjętego kontekstu. Dość wspomnieć, że bezpieczeństwo może być pojmowane $\mathrm{w}$ kategorii podstawowych potrzeb człowieka, stanu, procesu lub zasobu, jak również jako prawo każdego człowieka oraz element systemu wartości ${ }^{2}$.

${ }^{1}$ S. Koziej, Bezpieczeństwo: istota, podstawowe kategorie i historyczna ewolucja, „Bezpieczeństwo Narodowe" 2, 2011, nr 18, s. 19.

2 A. Czupryński, Bezpieczeństwo w ujęciu teoretycznym, [w:] Bezpieczeństwo: teoria, badania, praktyka, rẹd. A. Czupryński, B. Wiśniewski, J. Zboina, Józefów 2015, s. 9-24.

Forum Socjologiczne 10,2020

(C) for this edition by CNS 
W niniejszym opracowaniu skupiono się na tym aspekcie bezpieczeństwa, który charakteryzowany jest poprzez określenie podmiotu odniesienia. W tym sensie

bezpieczeństwo danego podmiotu to ta dziedzina jego aktywności, której treścią jest zapewnianie możliwości przetrwania (egzystencji) i swobody realizacji własnych interesów w niebezpiecznym środowisku, w szczególności poprzez wykorzystywanie szans (okoliczności sprzyjających), stawianie czoła wyzwaniom, redukowanie ryzyka oraz przeciwdziałanie (zapobieganie i przeciwstawianie się) wszelkiego rodzaju zagrożeniom dla podmiotu i jego interesów ${ }^{3}$.

W rozważaniach wielu autorów coraz więcej miejsca poświęca się zagadnieniu bezpieczeństwa jednostki. Można je scharakteryzować jako

ograniczenie do minimum przeżyć negatywnych jednostki, wynikających z jej uczestnictwa w życiu społecznym, które przejawiają się w postaci lęku lub strachu. Są to stany emocjonalne, które człowiek przeżywa na co dzień i których nie sposób uniknąć. Lęk dotyczy zagrożeń społecznych, np. przed utratą pracy, rozpadem związku, egzaminem. Strach natomiast jest właściwy dla sytuacji zagrożenia fizycznego, np. doznanie uszczerbku na zdrowiu w wyniku napaści lub wypadku${ }^{4}$.

Nie sposób zatem nie spostrzec, iż bezpieczeństwo personalne ma fundamentalne znaczenie we wszystkich obszarach życia człowieka i stanowi nierozerwalny element jego egzystencji.

Warto w tym miejscu poświęcić chwilę samemu pojęciu zagrożeń. Można je zdefiniować jako

towarzyszące ludzkiej cywilizacji zdarzenia i procesy [...] powodujące naruszenie równowagi [...]. Dotyczą one nie tylko będących w stałych powiązaniach lub wchodzących w stałe korelacje różnych podmiotów społeczno-politycznych (jednostek, grup społecznych, państw, związków państw), lecz także wszystkich składników, które tworzą materialne i duchowe środowisko życia człowieka. Wspomniane procesy i zdarzenia, przybierając konkretne formy - kataklizmów, katastrof, epidemii, wojen, patologii społecznych [...] - tworzą istotne przeszkody dla skutecznej ochrony wartości tworzących fundamenty bezpieczeństwa (życia, zdrowia, wolności, jakości egzystencji, perspektyw rozwoju $)^{5}$.

Zagrożenie jest zatem kluczową kategorią, nieustannie oddziałującą na bezpieczeństwo personalne. Oczywistym jest, że w dążeniach jednostki pojawia się chęć odsunięcia od siebie owych zagrożeń, zapobieganie im, powodowanie, aby nigdy nie wystąpiły. Z punktu widzenia bezpieczeństwa personalnego poczucie zagrożenia częściej wynika z obawy o codzienny byt, niż ze strachu przed zagrożeniami o charakterze globalnym ${ }^{6}$.

Dynamiczne i trudne do przewidzenia zmiany współczesnego środowiska bezpieczeństwa, wielorakie i złożone rodzaje wyzwań i zagrożeń prowokują do rozważań na temat przygotowania społeczeństwa na te zjawiska. Szczególne miejsce w tych

3 S. Koziej, op. cit., s. 20.

4 A. Czubaj, Miejsce jednostki we współczesnym pojmowaniu bezpieczeństwa, „De Securitate et Defensione. O Bezpieczeństwie i Obronności” 1 (2), 2016, s. 65.

5 B. Wiśniewski, Bezpieczeństwo w teorii i badaniach naukowych, Szczytno 2011, s. 25.

6 A. Czubaj, op. cit., s. 65.

Forum Socjologiczne 10, 2020

(C) for this edition by CNS 
rozważaniach zajmuje grupa niezwykle istotna z punktu widzenia kształtu przyszłego społeczeństwa i jego postaw w obszarze bezpieczeństwa - dzieci i młodzież. Aby skutecznie kształtować prawidłowe i dojrzałe zachowania w tym zakresie, należy dążyć do uświadamiania, czym jest zagrożenie, a także wyposażać w umiejętności rozpoznawania ich, unikania i eliminacji. W tym aspekcie wspieranie rozwoju młodego pokolenia polegać powinno przede wszystkim na przekazywaniu wartości zgodnych z normami współżycia społecznego. Doświadczenia edukacji dla bezpieczeństwa pozwalają stwierdzić, że istnieje wiele podmiotów angażujących się $\mathrm{w}$ proces przekazywania wiedzy i umiejętności w tym zakresie. Oprócz fundamentalnej roli socjalizacji w rodzinie ${ }^{7}$ edukacja dla bezpieczeństwa dzieci i młodzieży realizowana jest w znaczącej mierze w szkołach. Służy ona przygotowaniu uczniów do właściwego zachowania oraz odpowiednich reakcji w sytuacjach stwarzających zagrożenie dla zdrowia i życia. Jak stwierdził R. Rosa

edukacja w ogóle, a edukacja dla bezpieczeństwa i pokoju w szczególności, służyć mogą w zdobywaniu odpowiedniej wiedzy, kształtowaniu umiejętności, postaw i systemów wartości sprzyjających budowaniu i ochronie bezpiecznego i pokojowego świata ${ }^{8}$.

Analizując podstawę programową edukacji dla bezpieczeństwa w ramach szkolnictwa powszechnego ${ }^{9}$, należy zauważyć, iż $\mathrm{w}$ minimalnym stopniu zajmuje się ona zagrożeniami wynikającymi z możliwości stania się ofiarą bądź sprawcą przestępstwa, jak również rzadko odnosi się do zagrożeń związanych z pospolitymi patologiami społecznymi, jak chociażby uzależnienia. Tymczasem patologie i przestępczość są problemem, który często wywołuje poczucie zagrożenia personalnego w społeczeństwie, „nasilają się postawy punitywne wobec sprawców, społeczeństwo zaczyna się domagać ostrzejszej represji karnej [...], wtórują temu politycy [...]. Zmienia się polityka kryminalna w kierunku represyjnym w polityce karnej”" ${ }^{\prime \prime}$. Występowanie zagrożeń związanych $\mathrm{z}$ nieprzestrzeganiem ogólnie przyjętych norm, dewiacjami i różnego rodzaju patologiami społecznymi powoduje chęć obrony przed skutkami takich zachowań. Jednostka, oczekując szeroko rozumianego bezpieczeństwa, dostrzega potrzebę stosowania różnych metod, które to bezpieczeństwo zagwarantują. Jak zauważa Brunon Hołyst: „zjawisko przestępstwa będzie

${ }^{7}$ B. Sikorski, Przygotowanie dzieci i młodzieży do bezpiecznego działania $i$ współdziałania w środowisku naturalnym, [w:] Przygotowanie dzieci i młodzieży do działania w sytuacjach zagrożenia zdrowia i życia, red. M. Cieślarczyk et al., Siedlce 2008, s. 30.

${ }^{8}$ R. Rosa, Edukacja do bezpieczeństwa i pokoju w obliczu wyzwań XXI wieku, cz. 1. Filozoficzne i teoretyczne aspekty bezpieczeństwa i pokoju, Siedlce 2001, s. 14.

${ }^{9}$ Rozporządzenie Ministra Edukacji Narodowej z dnia 14 lutego 2017 r. w sprawie podstawy programowej wychowania przedszkolnego oraz podstawy programowej kształcenia ogólnego dla szkoły podstawowej, w tym dla uczniów z niepełnosprawnością intelektualną w stopniu umiarkowanym lub znacznym, kształcenia ogólnego dla branżowej szkoły I stopnia, kształcenia ogólnego dla szkoły specjalnej przysposabiającej do pracy oraz kształcenia ogólnego dla szkoły policealnej (Dz.U. z 2017 r. poz. 356).

10 T. Cielecki, Prewencja kryminalna. Studium z profilaktyki kryminologicznej, Opole 2004, s. 9.

Forum Socjologiczne 10, 2020

(C) for this edition by CNS 
wyjątkowo trudne do opanowania, jeśli organy władzy państwowej, a także szerokie kręgi społeczeństwa nie podejmą wysiłków w kierunku ograniczenia przyczyn i warunków jego dokonywania"11. Z punktu zaś widzenia przeciwdziałania temu zjawisku niezwykle istotne jest podnoszenie świadomości społecznej w tym aspekcie. Bezpieczeństwo łatwiej bowiem zapewnić poprzez zapobieganie niż późniejszą interwencję i niwelowanie skutków jego naruszenia ${ }^{12}$.

W niniejszym referacie zaprezentowano wyniki badań ankietowych mających na celu zidentyfikowanie potrzeb i oczekiwań uczniów szkół podstawowych i gimnazjów wobec edukacji na rzecz tego wycinka bezpieczeństwa osobistego. Przystępując do realizacji badań, punktem wyjścia uczyniono stwierdzenie, że aby skutecznie oddziaływać na młodzież w zakresie bezpiecznych zachowań, należy dokonywać analizy zagrożeń charakterystycznych dla regionu, jak również diagnozować potrzeby samych odbiorców. Badaniami objęto grupę uczniów klas ósmych szkół podstawowych oraz klas trzecich gimnazjów z trzech szkół znajdujących się na terenie Garwolina - jednego z miast powiatowych w województwie mazowieckim. Łącznie w badaniach wzięło udział 238 osób. Celem badań było zdefiniowanie oczekiwań i potrzeb edukacyjnych młodzieży w kwestii bezpieczeństwa personalnego, ograniczonego do zagrożeń związanych z przestępczością i patologiami społecznymi, które mogą stanowić podstawę do implementacji wskazywanych przez respondentów kwestii w działania szkół i instytucji realizujących zadania na rzecz bezpieczeństwa $\mathrm{w}$ regionie.

Badani uczniowie zostali poproszeni o wskazanie zagrożeń, na których temat mają najniższy poziom wiedzy (tabela 1). Najwięcej respondentów (41\%) zaliczyło do nich uzależnienia behawioralne. Taki stan rzeczy jest nieadekwatny wobec alarmujących danych, informujących o coraz wyższej skali tego problemu w Polsce, zwłaszcza jeżeli chodzi o nadużywanie mediów cyfrowych. Odsetek nastolatków dysfunkcyjnie korzystających z sieci, czyli nadużywających internetu lub zagrożonych nadużywaniem wynosi $13,3 \%$, jednak o wiele więcej z nich wykazuje pojedyncze symptomy takich zachowann ${ }^{13}$. Fakt ten nie może dziwić w zestawieniu z wynikami badań przeprowadzonych przez Instytut Badawczy NASK w 2016 roku. Wynika $\mathrm{z}$ nich, że ponad 93\% badanych korzysta $\mathrm{z}$ internetu $\mathrm{w}$ domu codziennie, a ponad $31 \%$ respondentów wskazało, że korzysta ze smartfonów ponad 5 godzin dziennie ${ }^{14}$. Niewielki poziom wiedzy na temat uzależnień behawioralnych może skutkować bagatelizowaniem problemu i nadmiernym bądź patologicznym angażowaniem się w wykonywanie niektórych czynności, pomimo negatywnych

${ }^{11}$ B. Hołyst, Pojęcie i zakres profilaktyki kryminalistycznej, [w:] idem, Kryminalistyka, Warszawa 2000, s. 1108.

12 A. Czubaj, op. cit., s. 65.

${ }^{13}$ EU NET ADB. Badanie nadużywania Internetu przez młodzież w Polsce, Fundacja Dzieci Niczyje (2013), https://www.saferinternet.pl/images/stories/pdf/raport-eu-net-adb-pl-final.pdf (dostęp: 2.05.2019).

${ }^{14}$ Nastolatki 3.0. Wybrane wyniki ogólnopolskiego badania uczniów w szkołach, https://akademia.nask.pl/publikacje/Raport_z_badania_Nastolatki_3_0.pdf (dostęp: 2.05.2019).

Forum Socjologiczne 10, 2020

(C) for this edition by CNS 
Tabela 1. Najniższy poziom wiedzy o zagrożeniach związanych z przestępczością i patologiami społecznymi w opinii badanych uczniów

\begin{tabular}{|l|c|c|}
\hline \multicolumn{1}{|c|}{ Na temat jakich zagrożeń masz najniższy poziom wiedzy? } & $\begin{array}{c}\text { Liczba badanych } \\
\text { (n=238) }\end{array}$ & $\%$ \\
\hline zagrożenia terrorystyczne & 58 & 24 \\
\hline uzależnienia chemiczne (od substancji psychoaktywnych) & 42 & 17,5 \\
\hline uzależnienia behawioralne (od czynności) & 97 & 41 \\
\hline oszustwa internetowe & 23 & 9,5 \\
\hline cyberprzemoc & 27 & 11,5 \\
\hline znajomości internetowe & 15 & 6,5 \\
\hline prywatność w sieci & 17 & 7 \\
\hline kradzieże & 53 & 22 \\
\hline włamania & 85 & 36 \\
\hline bójki, pobicia & 24 & 10 \\
\hline zagrożenia bezpieczeństwa w ruchu drogowym & 40 & 16,5 \\
\hline zagrożenia podczas imprez masowych (mecze, koncerty, & 77 & 32,5 \\
\hline zgromadzenia itp.) & 5 & 2 \\
\hline inne & & \\
\hline
\end{tabular}

Źródło: badanie własne.

konsekwencji. Zachowania, od których można się uzależnić, są elementem normalnego życia człowieka, dlatego trudno wyznaczyć granicę pomiędzy silnym zaangażowaniem wynikającym z pasji a początkami problemu. Może to mieć wpływ na bezpieczeństwo jednostki, powodując obniżenie jakości życia, zaniedbywanie relacji społecznych, a nawet lekceważenie podstawowych potrzeb fizjologicznych, takich jak sen czy jedzenie. Uzależnienia behawioralne bywają sposobem na modyfikowanie nastroju, nieprawidłowym sposobem na radzenie sobie ze stresem oraz źródłem konfliktów. Powodują dysfunkcyjne funkcjonowanie jednostki w społeczeństwie, a nadto kształtują model aspołecznych zachowań.

Wśród innych najczęściej wskazywanych zagrożeń, na temat których badani uczniowie deklarowali najniższy poziom wiedzy, znalazły się także włamania (36\%) oraz zagrożenia podczas imprez masowych $(32,5 \%)$. Stawiając sobie za cel zarówno wzrost poczucia bezpieczeństwa personalnego młodzieży, jak i kształtowanie ich prawidłowych postaw wobec tego typu zagrożeń, deficyty te niewątpliwie należy uzupełniać. Włamania są zagrożeniem $\mathrm{w}$ niemałym stopniu warunkującym poczucie bezpieczeństwa jednostki. Dotyczą bowiem obawy o utratę własnych dóbr materialnych, a także strachu przed napaścią, zagrażającą nie tylko mieniu, ale także zdrowiu

Forum Socjologiczne 10, 2020

(C) for this edition by CNS 
i życiu jednostki. Imprezy masowe zaś, takie jak koncerty lub mecze piłkarskie, są dla młodych ludzi atrakcyjnym rodzajem rozrywki. Młodzież chętnie uczestniczy w tego typu wydarzeniach, podczas gdy można im przypisać wysoki stopień zagrożenia bezpieczeństwa personalnego osób biorących w nich udział. Wśród owych zagrożeń wymienić można akty agresji, bójki, wybuch paniki, zamieszki itp. Niewielka wiedza o niebezpieczeństwach podczas imprez masowych świadczy o tym, że duża część młodych osób chętnie w nich uczestniczących nie potrafiłaby odpowiednio zareagować na wypadek wystąpienia jednej ze wspomnianych sytuacji.

Wśród zagrożeń, na temat których badani uczniowie ocenili swój poziom wiedzy jako najwyższy, znalazły się uzależnienia chemiczne (45\%), oszustwa internetowe $(35 \%)$ oraz bójki i pobicia (28\%). Szczegółowe dane w tej kwestii prezentuje tabela 2 .

Tabela 2. Najwyższy poziom wiedzy o zagrożeniach związanych z przestępczością i patologiami społecznymi w opinii badanych uczniów

\begin{tabular}{|l|c|c|}
\hline Na temat jakich zagrożeń masz najwyższy poziom wiedzy? & $\begin{array}{c}\text { Liczba badanych } \\
\text { (n=238) }\end{array}$ & $\%$ \\
\hline zagrożenia terrorystyczne & 55 & 23 \\
\hline uzależnienia chemiczne (od substancji psychoaktywnych) & 107 & 45 \\
\hline uzależnienia behawioralne (od czynności) & 31 & 13 \\
\hline oszustwa internetowe & 83 & 35 \\
\hline cyberprzemoc & 53 & 22,5 \\
\hline znajomości internetowe & 61 & 25,5 \\
\hline prywatność w sieci & 55 & 23 \\
\hline kradzieże & 28 & 12 \\
\hline włamania & 16 & 7 \\
\hline bójki, pobicia & 67 & 28 \\
\hline zagrożenia bezpieczeństwa w ruchu drogowym & 46 & 19.5 \\
\hline zagrożenia podczas imprez masowych (mecze, koncerty, & 22 & 9.5 \\
\hline zgromadzenia itp.) & - & - \\
\hline inne & & \\
\hline
\end{tabular}

Źródło: badanie własne.

Odpowiedzi te warto zestawić z deklaracjami respondentów, jakie zagrożenia w ich ocenie powinny być częściej omawiane na zajęciach (tabela 3). Ciekawy wydaje się fakt, iż uczniowie w największym stopniu wyrazili potrzebę częstszego podnoszenia kwestii związanych z uzależnieniami chemicznymi, pomimo że wcześniej zadeklarowali, iż na temat tego właśnie zagrożenia mają najwyższy poziom wiedzy.

Forum Socjologiczne 10, 2020

(C) for this edition by CNS 
Można zatem wysnuć wniosek, że jest to spowodowane wysoką skalą zagrożenia zjawiskiem zażywania alkoholu, narkotyków i dopalaczy przez młodzież w regionie $^{15}$, a zatem jest powodem chęci zdobycia przez młodzież wiedzy na ten temat.

Inaczej prezentują się wyniki w odniesieniu do zagrożeń, na których temat respondenci deklarowali najniższy poziom wiedzy. Dość często były one wskazywane jako te właśnie, które częściej powinny być omawiane w szkole. Oznacza to, że niski poziom wiedzy na temat poszczególnych zagrożeń determinuje oczekiwania uczniów w kwestii edukacji dla bezpieczeństwa.

Należy także zwrócić uwagę na wysoki odsetek odpowiedzi wskazujących na potrzebę częstszych zajęć związanych z zagrożeniami o charakterze terrorystycznym (27\%). Kwestia ta została ujęta w podstawie programowej, jednak uczniowie wyrazili postulat zwiększenia częstotliwości podejmowania tej tematyki. Może to oznaczać, że aspekty związane z zagrożeniami terrorystycznymi odzwierciedlone w programie nauczania są niewystarczające i należy je poszerzyć.

Wśród najczęstszych odpowiedzi w badanym aspekcie pojawił się także problem cyberprzemocy (22\%). Choć niewielka grupa respondentów wskazała to zagrożenie jako jedno z tych, o którym ma najniższy poziom wiedzy (11,5\%), to istotna część zadeklarowała oczekiwanie częstszych zajęć poruszających tę problematykę. Deklaracje te są zrozumiałe w odniesieniu do skali i specyfiki zjawiska. Z badań przeprowadzonych w Polsce w 2007 roku wynika, że ponad połowa młodych internautów (12-17 lat) miała do czynienia $\mathrm{z}$ przemocą werbalną $\mathrm{w}$ internecie lub za pośrednictwem telefonu komórkowego ${ }^{16}$. Według szacunków amerykańskich badaczy blisko 85\% adolescentów w wieku 12-13 lat miało doświadczenia z cyberprzemocą, z czego $10-42 \% \mathrm{z}$ nich było ofiarą tej formy agresji ${ }^{17}$.

Tabela 3. Oczekiwania badanych uczniów w kwestii edukacji dla bezpieczeństwa w szkole

\begin{tabular}{|l|c|c|}
\hline $\begin{array}{c}\text { Które z poniższych kwestii powinny być częściej } \\
\text { podnoszone w ramach edukacji dla bezpieczeństwa } \\
\text { w szkole? }\end{array}$ & $\begin{array}{c}\text { Liczba badanych } \\
\text { (n=238) }\end{array}$ & $\%$ \\
\hline zagrożenia terrorystyczne & 64 & 27 \\
\hline uzależnienia chemiczne (od substancji psychoaktywnych) & 96 & 40,5 \\
\hline uzależnienia behawioralne (od czynności) & 46 & 19,5 \\
\hline
\end{tabular}

$15 \mathrm{Z}$ badań przeprowadzonych przez autorkę w lutym 2018 r. na grupie 144 niepełnoletnich uczniów szkół średnich z powiatu garwolińskiego wynika, że w grupie rówieśniczej aż 49\% badanych uczniów zna kogoś, kto zażywa narkotyki lub dopalacze (praca magisterska napisana pod kierunkiem dr hab. Agaty Tyburskiej, Profilaktyka uzależnień wobec zjawiska zażywania narkotyków i dopalaczy przez uczniów szkół średnich, Wyższa Szkoła Policji w Szczytnie, 2018).

16 Ł. Wojtasik, Przemoc rówieśnicza a media elektroniczne, „Dziecko krzywdzone. Teoria, badania, praktyka” 8 (1), 2009, s. 79.

17 D. Sarzała, M. Z. Jędrzejko, Cyberprzemoc rówieśnicza - analiza problemu i destruktywnego wymiaru zjawiska, [w:] Cyfrowe dzieci. Zjawisko, uwarunkowania, kluczowe problemy, S. Bębas et al., Warszawa-Milanówek 2017, s. 200.

Forum Socjologiczne 10, 2020

(C) for this edition by CNS 


\begin{tabular}{|l|c|c|}
\hline oszustwa internetowe & 41 & 17 \\
\hline cyberprzemoc & 52 & 22 \\
\hline znajomości internetowe & 35 & 15 \\
\hline prywatność w sieci & 37 & 15,5 \\
\hline kradzieże & 38 & 16 \\
\hline włamania & 24 & 10 \\
\hline bójki, pobicia & 55 & 23 \\
\hline zagrożenia bezpieczeństwa w ruchu drogowym & 24 & 10 \\
\hline $\begin{array}{l}\text { zagrożenia podczas imprez masowych (mecze, koncerty, } \\
\text { zgromadzenia itp.) }\end{array}$ & 43 & 18 \\
\hline inne & 5 & 2 \\
\hline
\end{tabular}

Źródło: badanie własne.

Na pytanie o to, kto powinien przeprowadzać zajęcia na temat przestępczości i patologii społecznych, zdecydowanie najwięcej respondentów odpowiedziało, że policjant (52,5\%). Tak wysoki odsetek badanych, którzy wskazali tę właśnie odpowiedź, obliguje do szerszego omówienia tej kwestii. Ustawa o Policji definiuje tę formację jako organizację służącą społeczeństwu i przeznaczoną do ochrony bezpieczeństwa ludzi oraz do utrzymywania bezpieczeństwa i porządku publicznego (art. 1 ust.1) ${ }^{18}$. Przepisy wyznaczają funkcjonariuszom szereg zadań, wśród których jednym z priorytetów jest inicjowanie i organizowanie działań mających na celu zapobieganie popełnianiu przestępstw i wykroczeń oraz zjawiskom kryminogennym i współdziałanie w tym zakresie z organami państwowymi, samorządowymi i organizacjami społecznymi (art. 1 ust. 2 pkt 3). Zasadne zatem jest podkreślenie, że w ramach realizacji tych zadań policjanci angażują się w zajęcia edukacyjne realizowane w szkołach z zakresu szeroko pojętego bezpieczeństwa. Najczęściej spotkania z dziećmi i młodzieżą przeprowadzane są przez funkcjonariuszy z komórek do spraw profilaktyki społecznej, nieletnich i patologii poszczególnych jednostek policji. Warto zatem zastanowić się, czy policjanci ci są odpowiednio przygotowani do tej roli, według jakich kryteriów prowadzony jest dobór na tego typu stanowiska i czy zakres szkoleń, które przechodzą w tym zakresie, jest adekwatny i wystarczający, aby uświadamiać i wyczulać młodych ludzi na zagrożenia związane z patologiami społecznymi i przestępczością, ale także kształtować ich postawy. Wydaje się bowiem, że oprócz doświadczenia zawodowego oraz wiedzy w kwestiach związanych z bezpieczeństwem personalnym jednostki niezwykle istotna jest umiejętność przekazania treści w sposób jasny, zrozumiały oraz ciekawy. Charakter zadań stawianych przed policjantami

18 Ustawa z dnia 6 kwietnia 1990 r. o Policji (Dz.U. 1990 Nr 30, poz. 179 z późn. zm.). 
na tym stanowisku wymaga zarówno szerokiej wiedzy, doświadczenia zawodowego, jak i umiejętności pedagogicznych, psychologicznych i komunikacyjnych. Działania profilaktyczne zbliżone są bowiem do działań wychowawczych. Z pewnością jest to temat, który wymaga głębszej analizy i diagnozy.

Na uwagę zasługuje także fakt, że oprócz programów autorskich realizowanych przez poszczególne jednostki, które są ukierunkowane na bezpieczeństwo dzieci i młodzieży, szkoły niejednokrotnie same inicjują spotkania z funkcjonariuszami, jednak działania te często są reakcją post factum co do jakiegoś zdarzenia (bywają odpowiedzią na ujawniony fakt cyberprzemocy, bójki, kradzieży bądź innego incydentu zaistniałego w szkole). Tymczasem sprowadzanie tego typu zajęć do akcyjności, jednorazowości, a także traktowanie ich jako działania zaradcze, umniejsza ich rolę i efektywność profilaktyczną.

Odrębną kwestią jest także możliwość wygenerowania dodatkowych godzin lekcyjnych, które mogłyby zostać poświęcone przedmiotowej tematyce. Wydaje się bowiem, że bez implementacji kwestii związanych $\mathrm{z}$ bezpieczeństwem personalnym do programów nauczania organizowanie tego typu zajęć kosztem chociażby godzin wychowawczych może być poważnie utrudnione. Wygospodarowany czas nie będzie bowiem wystarczający, a zajęcia zostaną obarczone piętnem wyrywkowości i akcyjności.

Tabela 4. Oczekiwania uczniów w kwestii prowadzących zajęcia na temat zagrożeń związanych z przestępczością i patologiami społecznymi

\begin{tabular}{|l|c|c|}
\hline Kto powinien przeprowadzać takie zajęcia? & $\begin{array}{c}\text { Liczba badanych } \\
\text { (n=238) }\end{array}$ & $\%$ \\
\hline nauczyciel & 21 & 9 \\
\hline wychowawca & 14 & 6 \\
\hline pedagog & 23 & 9,5 \\
\hline psycholog & 29 & 12 \\
\hline rodzic & 4 & 1,5 \\
\hline policjant & 125 & 52,5 \\
\hline Inna osoba & 22 & 9 \\
\hline
\end{tabular}

Źródło: badanie własne.

Wśród innych osób wskazywanych przez uczniów jako te, które powinny przeprowadzać zajęcia z zakresu bezpieczeństwa personalnego, niewielki odsetek odpowiedzi wskazywał na psychologów, dalej pedagogów oraz nauczycieli (tabela 4). W świetle uzyskanych wyników należy stwierdzić, iż rola współpracy szkół i policji w omawianym obszarze jest zatem ogromna. Warto podkreślić, że $9 \%$ respondentów podało własne propozycje w tym aspekcie. Najczęściej wskazywano na osoby z zewnątrz, które znalazły się w sytuacji poszczególnych zagrożeń. 
W dalszej części procedury badawczej podjęto próbę zweryfikowania deklaracji respondentów na temat poziomu ich wiedzy w kwestii poszczególnych zagrożeń. $62,5 \%$ badanych zadeklarowało, że wiedziałoby, w jaki sposób zachować się w razie wystąpienia zdarzenia o charakterze terrorystycznym (tabela 5). Jednocześnie uczniowie ci prawidłowo wymieniali zasady, jakimi należy się kierować $w$ takiej sytuacji. Wielokrotnie podkreślali znaczenie zachowania spokoju i podporządkowania ewentualnym terrorystom. Badani wskazywali algorytm postępowania $\mathrm{w}$ przypadku takiego zdarzenia, jak poszukiwanie ukrycia, zasłonienie się jakąś przeszkodą, ułożenie się na podłodze, wykonywanie poleceń terrorysty, wezwanie służb ratunkowych, współdziałanie. Oczywiście zdarzenia o charakterze terrorystycznym mogą mieć różnorodny charakter, jednakże pewne procedury postępowania pozostaną stałe. $\mathrm{Z}$ analizy wyników badań wynika, że zarówno deklarowany, jak i teoretyczny poziom wiedzy badanych w tej kwestii kształtuje się na zadowalającym poziomie, jednak nie sposób nie zauważyć, że ten rodzaj zagrożeń uczniowie chcieliby częściej omawiać podczas zajęć szkolnych. Może to świadczyć o tym, że świadomość możliwości wystąpienia tego typu zdarzenia ma znaczny wpływ na poczucie bezpieczeństwa personalnego. Znając sposoby rozpoznawania symptomów ewentualnego zagrożenia, a także bezpiecznego reagowania, na nie można nie dopuścić do jego przeprowadzenia. Z kolei znajomość procedur reagowania $\mathrm{w}$ przypadku wystąpienia ataku terrorystycznego może decydować o skali jego negatywnych skutków ${ }^{19}$. Doniesienia medialne ukazujące częstokroć mnogość przypadkowych ofiar ataków z pewnością wzmagają potrzebę przygotowania się na wypadek wystąpienia podobnej sytuacji.

Tabela 5. Zagrożenia terrorystyczne

\begin{tabular}{|c|c|c|}
\hline $\begin{array}{c}\text { Czy wiesz, w jaki sposób zachować się w razie } \\
\text { wystąpienia zdarzenia 0 charakterze terrorystycznym? }\end{array}$ & $\begin{array}{c}\text { Liczba badanych } \\
\text { (n=238) }\end{array}$ & $\%$ \\
\hline tak & 149 & 62,5 \\
\hline nie & 87 & 37,5 \\
\hline
\end{tabular}

Źródło: badanie własne.

W odniesieniu do uzależnień od substancji psychoaktywnych badani deklarowali zdecydowanie wysoki poziom wiedzy, jak również - najczęściej - wskazali chęć częstszego podejmowania tej tematyki w ramach edukacji dla bezpieczeństwa. Do weryfikacji subiektywnych odczuć respondentów w tym zakresie posłużono się pytaniem o podmioty mogące pomóc osobom uzależnionym na przykład od alkoholu. $75 \%$ badanych prawidłowo wskazywało instytucje świadczące pomoc w tej kwestii (klub AA, lekarze, ośrodki terapii uzależnień, psychologowie itp.). Badani

${ }^{19} \mathrm{http} / / /$ www.antyterroryzm.gov.pl/CAT/antyterroryzm/poradniki/555,Poradniki.html (dostęp: 6.05.2019). 
wskazywali również na dużą rolę rodziny, przyjaciół oraz nauczycieli i pedagogów w tej kwestii (tabela 6). Skala zagrożeń związana z używaniem substancji psychoaktywnych, zwłaszcza przez osoby niepełnoletnie, jest ogromna — od konsekwencji zdrowotnych, po prawne i psychospołeczne. W odniesieniu do bezpieczeństwa personalnego nie można zatem pominąć tego obszaru tematycznego, tym bardziej że potencjalni odbiorcy przedmiotowych treści także wyrazili taki postulat.

Tabela 6. Uzależnienia chemiczne

\begin{tabular}{|c|c|c|}
\hline $\begin{array}{c}\text { Czy wiesz, gdzie szukać pomocy w kwestii uzależnień } \\
\text { chemicznych np. od alkoholu? }\end{array}$ & $\begin{array}{c}\text { Liczba badanych } \\
\text { (n=238) }\end{array}$ & $\%$ \\
\hline tak & 179 & 75 \\
\hline nie & 59 & 25 \\
\hline
\end{tabular}

Źródło: badanie własne.

W odniesieniu do uzależnień behawioralnych, na których temat ankietowani zadeklarowali najniższy poziom wiedzy, poproszono uczniów o określenie w pięciostopniowej skali, w jakim stopniu możliwe jest uzależnienie się od internetu. Najwięcej osób (43\%) wskazało, że zdecydowanie jest to możliwe (tabela 7). Respondenci zdają sobie sprawę z istnienia takiego zagrożenia, jednak niewielu z nich chciałoby mieć więcej zajęć poświęconych tej tematyce. Przedmiotem odrębnej analizy można by uczynić powody takiej postawy - czy wynikają one z bagatelizowania problemu, czy też braku świadomości negatywnych konsekwencji związanych z uzależnieniami behawioralnymi.

Tabela 7. Uzależnienia behawioralne

\begin{tabular}{|c|c|c|}
\hline $\begin{array}{c}\text { W jakim stopniu możliwe jest uzależnienie się } \\
\text { od internetu? }\end{array}$ & $\begin{array}{c}\text { Liczba badanych } \\
\text { (n=238) }\end{array}$ & $\%$ \\
\hline 1 & 10 & 4 \\
\hline 2 & 28 & 12 \\
\hline 3 & 46 & 19 \\
\hline 4 & 52 & 22 \\
\hline 5 & 102 & 43 \\
\hline
\end{tabular}

(w skali od 1 - w ogóle nie jest możliwe, do 5 — zdecydowanie jest możliwe)

Źródło: badanie własne.

Dosyć zaskakująco rozkładają się odpowiedzi dotyczące zjawiska cyberprzemocy (tabela 8). Choć w przypadku stania się ofiarą tego typu działań $43 \%$ uczniów powiedziałoby o tym swoim rodzicom, to jedynie $20 \%$ zgłosiłoby tę sprawę na policję. Wtórują temu stwierdzenia, że cyberprzemoc nie jest przestępstwem lub że sprawca 
nie poniesie odpowiedzialności. Świadczy to o niewielkiej świadomości ankietowanych o wybranych regulacjach prawnych znajdujących zastosowanie w tej kwestii oraz że ofiara jest chroniona zarówno przez prawo karne, jak i cywilne. Przepisy prawne, które obejmują swym zakresem zachowania sprawców to między innymi art. 212 k.k. (zniesławienie), art. 216 k.k. (zniewaga), art. 267 i 268a k.k. (włamanie), art. 190 i 191 k.k. (groźby), art. 190a k.k. (nękanie), art. 23 i 24 k.c. (naruszenie wizerunku dziecka) ${ }^{20}$. Z pewnością zatem wiedza młodych osób na temat cyberprzemocy jest niewystarczająca. I choć zapewne respondenci są w stanie rozpoznać takie zachowania, to niewielu $\mathrm{z}$ nich wie, $\mathrm{w}$ jaki sposób sobie z nimi radzić. Warto także zwrócić uwagę na stosunkowo wysoki odsetek uczniów, którzy zadeklarowali, że w podobnej sytuacji zachowaliby się w inny sposób (13\%) - najczęściej nie reagowaliby w ogóle na takie zachowania lub sami by sobie z tym poradzili, nie opisując, w jaki sposób.

Tabela 8. Cyberprzemoc

\begin{tabular}{|l|c|c|}
\hline Jak byś się zachował, gdybyś stał się ofiarą cyberprzemocy? & $\begin{array}{c}\text { Liczba badanych } \\
\text { (n=238) }\end{array}$ & \% \\
\hline nie szukałbym pomocy, bo to wstyd & 12 & 5 \\
\hline $\begin{array}{l}\text { nie szukałbym pomocy, bo i tak sprawca nie poniesie } \\
\text { odpowiedzialności }\end{array}$ & 10 & 4 \\
\hline nie szukałbym pomocy, bo nie wiem gdzie & 10 & 4 \\
\hline nie szukałbym pomocy, bo to zdarza się często & 7 & 3 \\
\hline nie szukałbym pomocy, bo to nie przestępstwo & 12 & 5 \\
\hline zgłositbym to nauczycielowi & 103 & 43 \\
\hline zgłositbym to rodzicom & 48 & 20 \\
\hline zgłositbym to na policję & 31 & 13 \\
\hline zachowałbym się w inny sposób (jaki?) & 71 \\
\hline
\end{tabular}

Źródło: badanie własne.

Chcąc poznać świadomość respondentów na temat prywatności w sieci, poproszono ich, by ustosunkowali się do publikowania własnych zdjęć w internecie (tabela 9). Największy odsetek osób wskazał, że to bezpieczne, pod warunkiem że profil jest prywatny (29\%), dalej - najwięcej osób stwierdziło, że wszyscy tak robią, więc jest to bezpieczne $(24,5 \%)$. Równie wiele odpowiedzi brzmiało, że to bezpieczne, pod warunkiem że zdjęcie przesyłane jest bliskiej osobie (22\%). Osoby, które zdecydowały się na opisanie własnego stanowiska, najczęściej podkreślały, że wysyłanie zdjęć jest dozwolone, lecz trzeba uważać, by nie były one

${ }^{20}$ Ł. Wojtasik, Cyberprzemoc, [w:] Bezpieczeństwo dzieci online. Kompendium dla rodziców i profesjonalistów, red. A. Wrzesień-Gandolfo, Warszawa 2015, s. 19.

Forum Socjologiczne 10, 2020

(C) for this edition by CNS 
kompromitujące bądź nagie. Jedynie 11\% uczniów uznało, że publikowanie własnych zdjęć w internecie jest niebezpieczne. Komentarzem do zaobserwowanych postaw uczniów może być opinia Anny Rywczyńskiej, która podkreśla, że

dla młodych ludzi konsekwencje niewłaściwego zarządzania swoją internetową reputacją często nie wydają się poważnym i realnym zagrożeniem. Wśród ryzykowanych zachowań, jakie podejmują online, jest m.in. publikowanie nieodpowiednich zdjęć i filmów [...] czy też upublicznianie prywatnych informacji lub danych nieograniczonemu gronu odbiorców. [...] Te materiały bardzo często trafiają później w niepowołane ręce, a ich rozprzestrzenianie się w sieci jest już w zasadzie nie do zablokowania ${ }^{21}$.

Tabela 9. Prywatność w internecie

\begin{tabular}{|l|c|c|}
\hline \multicolumn{1}{|c|}{ Co sądzisz o publikowaniu własnych zdjęć w internecie? } & $\begin{array}{c}\text { Liczba badanych } \\
\text { (n=238) }\end{array}$ & \% \\
\hline to bezpieczne, wszyscy tak robią. & 58 & 24,5 \\
\hline $\begin{array}{l}\text { to bezpieczne, pod warunkiem, że wysyłam zdjęcie tylko } \\
\text { do bliskiej mi osoby. }\end{array}$ & 53 & 22 \\
\hline $\begin{array}{l}\text { to bezpieczne, pod warunkiem, że mój profil } \\
\text { jest prywatny. }\end{array}$ & 69 & 29 \\
\hline to niebezpieczne. & 26 & 11 \\
\hline Uważam, że... & 32 & 13.5 \\
\hline
\end{tabular}

Źródło: badanie własne.

W tabeli 10 zaprezentowano odpowiedzi uczniów na temat pozostałych zagrożeń branych pod uwagę w badaniu. Na pytanie w kwestii bezpieczeństwa związanym ze znajomościami internetowymi $62 \%$ ankietowanych stwierdziło, że wie, jak bezpiecznie zaaranżować spotkanie z osobą, którą poznało się w sieci. Prawidłowo też podawali zasady, jakimi powinna kierować się osoba w takim przypadku (poinformować osobę dorosłą o spotkaniu, spotkać się w miejscu, gdzie jest dużo osób, iść z inną osobą itp.). $70 \%$ respondentów w sposób prawidłowy wskazywało, $\mathrm{w}$ jaki sposób zabezpieczyć się przed włamaniem do mieszkania (zabezpieczenia techniczne, takie jak sprawne zamki, alarmy, kamery; poinformowanie osób z rodziny lub sąsiadów, by doglądali gospodarstwa w czasie nieobecności domowników itp.). Pomimo wysokiej świadomości na temat zabezpieczeń technicznych i innych środków ostrożności przed włamaniem należy przypomnieć, że respondenci subiektywnie ocenili poziom swojej wiedzy na temat tego zagrożenia jako niski. Również kwestie związane z zasadami bezpieczeństwa w ruchu drogowym nie stanowiły problemu dla respondentów. $84 \% \mathrm{z}$ nich wymieniło właściwie czynności i zasady zachowania się pieszego, by bezpiecznie przejść przez jezdnię

21 A. Rywczyńska, Reputacja online, [w:] Bezpieczeństwo dzieci online. Kompendium dla rodziców i profesjonalistów, red. A. Wrzesień-Gandolfo, Warszawa 2015 s. 84.

Forum Socjologiczne 10, 2020

(C) for this edition by CNS 
(zachować szczególną ostrożność, rozejrzeć się, nie wbiegać na jezdnię, upewnić się, że nic nie jedzie, korzystać z przejść dla pieszych, nie wygłupiać się, nie patrzeć na ekran smartfonu itp.). W aspekcie bezpieczeństwa podczas imprez masowych uczniowie mieli wskazać przedmioty, których nie można posiadać przy sobie podczas meczu piłkarskiego. Niespełna $70 \%$ ankietowanych trafnie potrafiło wymienić przynajmniej jedną nielegalną rzecz (noże, broń palna, materiały pirotechniczne, substancje łatwopalne wskazane $\mathrm{w}$ regulaminie przez organizatora itp.). 54\% ankietowanych potrafiło także wskazać zasady, jakimi należy się kierować, aby uniknąć oszustów internetowych (sprawdzać wiarygodność stron internetowych, nie podawać niepotrzebnie swoich danych, dokonywać zakupu z płatnością przy odbiorze, chronić loginy i hasła itp.). Wysoki zatem zdaje się odsetek osób, które przyznały, że nie mają wiedzy na ten temat (46\%). Na uwagę zasługuje fakt, że aż 70,5\% badanych uczniów nie potrafiło określić praw, jakie przysługują ofierze pobicia, choć odpowiedź zdawała się intuicyjna. Niewiele osób wskazało chociażby na możliwość zawiadomienia organów ścigania czy prawo do ewentualnego zadośćuczynienia.

Tabela 10. Pozostałe zagrożenia

\begin{tabular}{|l|c|c|c|}
\hline \multicolumn{1}{|c|}{ Treść pytania } & Odpowiedź & $\begin{array}{c}\text { Liczba badanych } \\
\text { (n=238) }\end{array}$ & $\%$ \\
\hline $\begin{array}{l}\text { Czy wiesz, jak bezpiecznie zaaranżować spotkanie } \\
\text { z osobą poznaną przez internet w realnym } \\
\text { świecie? }\end{array}$ & tak & 147 & 62 \\
\cline { 2 - 4 } & nie & 91 & 38 \\
\hline \multirow{2}{*}{$\begin{array}{l}\text { Czy wiesz, jak zabezpieczyć dom przed włamaniem, } \\
\text { np. przed wyjazdem? }\end{array}$} & tak & 166 & 70 \\
\cline { 2 - 4 } & nie & 72 & 30 \\
\hline \multirow{2}{*}{\begin{tabular}{l} 
Czy wiesz, jakie prawa przysługują ofierze pobicia? \\
\cline { 2 - 4 }
\end{tabular}} & tak & 70 & 29,5 \\
\hline \multirow{2}{*}{$\begin{array}{l}\text { Czy wiesz, jak powinien zachowywać się pieszy } \\
\text { przechodzący przez jezdnię, aby nie stwarzać } \\
\text { zagrożenia bezpieczeństwa w ruchu drogowym? }\end{array}$} & tak & 200 & 70,5 \\
\cline { 2 - 4 } & nie & 38 & 168 \\
\hline \multirow{2}{*}{$\begin{array}{l}\text { Czy wiesz, jakich przedmiotów nie można mieć przy } \\
\text { sobie podczas meczu pitkarskiego? }\end{array}$} & tak & 165 & 69,5 \\
\cline { 2 - 4 } & nie & 73 & 30,5 \\
\hline \multirow{2}{*}{$\begin{array}{l}\text { Czy wiesz, jakich zasad należy przestrzegać, } \\
\text { aby nie stać się ofiarą oszustwa internetowego? }\end{array}$} & tak & 134 & 56 \\
\cline { 2 - 4 } & nie & 104 & 44 \\
\hline
\end{tabular}

Źródło: badanie własne. 
Zmierzając do podsumowania niniejszych rozważań, należy zauważyć, iż w dyskusji publicznej nie milkną głosy, że współczesna szkoła nie zaspokaja w pełni potrzeb edukacyjnych i wychowawczych w zakresie bezpieczeństwa. Tymczasem

młody człowiek powinien wejść w dorosłe życie już przygotowany do zapewnienia bezpieczeństwa sobie i innym. Warunkiem jest jednak, aby treści programowe były właściwie dobrane, a nauczyciele odpowiednio wykształceni i przygotowani ${ }^{22}$.

Przeprowadzona diagnoza potrzeb edukacyjnych w zakresie bezpieczeństwa personalnego wśród uczniów pozwala stwierdzić, że należy tę tematykę wpleść w działania szkoły oraz innych podmiotów działających na rzecz bezpieczeństwa. Będzie to zgodne zarówno z oczekiwaniami samych uczniów, jak i może odpowiadać na ujawnione deficyty młodzieży w tym zakresie.

Pozostający w zainteresowaniu autorki kontekst potrzeb edukacyjnych młodzieży w kwestii bezpieczeństwa personalnego, ograniczonego do zagrożeń związanych z przestępczością i patologiami społecznymi, doprowadził do jednoznacznego wniosku, że jest to aspekt niezwykle aktualny i istotny. Biorąc pod uwagę lokalne warunki i zagrożenia wynikające ze wskazań badanych, zasadne wydaje się podejmowanie w szkole takich tematów, jak uzależnienia behawioralne, uzależnienia chemiczne, cyberprzemoc i prywatność w sieci. Wśród podejmowanych kwestii powinny znaleźć się także agresja fizyczna, bójki i pobicia. Należy mieć także na uwadze fakt, że pomimo stosunkowo wysokiego poziomu wiedzy uczniów na temat zagrożeń o charakterze terrorystycznym, wielu z nich oczekuje większej ilości zajęć z tego zakresu. Powyższe rozwiązanie może stanowić podstawę do implementacji wymagających tego treści do działań szkoły oraz innych podmiotów, realizujących zadania z zakresu bezpieczeństwa.

Ukształtowanie świadomości na temat zagrożeń bezpieczeństwa personalnego, które mogą dotyczyć młodzieży, jak również świadomości uzyskania stosownej pomocy od właściwych organów i podmiotów państwa w takich sytuacjach powinno być celem edukacji dla bezpieczeństwa. W tym zakresie należy zwracać szczególną uwagę na wpajanie zasad bezpiecznego zachowania się w sytuacjach codziennych, w tym tych związanych $\mathrm{z}$ patologiami społecznymi oraz możliwością stania się ofiarą lub sprawcą przestępstwa. Należy pamiętać, że „dostosowanie programów kształcenia do reali lokalnych jest jednym z najważniejszych zadań współczesnej edukacji”23.

Jako że przeprowadzone badania w sposób jednoznaczny wykazały, że młodzież chciałaby, aby zajęcia związane z zagrożeniami patologiami społecznymi i przestępczością realizowane były w szkołach przez policjanta, należy zastanowić się nad możliwością włączenia funkcjonariuszy tej właśnie formacji w działania

${ }^{22}$ K. Sikora-Wojtarowicz, Edukacja dla bezpieczeństwa w polskiej szkole, „,Rocznik Bezpieczeństwa Międzynarodowego" 11, 2017, nr 1, s. 116.

${ }^{23}$ Z. Kwiasowski, Znaczenie edukacji dla bezpieczeństwa w wychowaniu obywatelskim, [w:] Edukacja dla bezpieczeństwa. Teoria i praktyka, red. A. Skrabacz, L. Kanarski, Warszawa 2014, s. 88.

Forum Socjologiczne 10, 2020

(C) for this edition by CNS 
szkół. Ów ważny postulat z pewnością nie będzie nastręczał większych problemów praktycznych ze względu na tożsame cele i zadania policji związane z profilaktyką i prewencją zachowań patologicznych oraz przestępczych, realizowane przede wszystkim przez wyznaczonych w jednostkach funkcjonariuszy - specjalistów z zakresu profilaktyki społecznej. Rekomendacją w tej kwestii będzie zatem udział takiego policjanta w zajęciach szkolnych, uwzględniających tematykę bezpieczeństwa osobistego, zindywidualizowaną na podstawie badań. Ważniejszą jednak kwestią wydaje się doprowadzenie do systematyczności i ciągłości współpracy szkół i komend policji w tym zakresie, która, póki co, musi opierać się o indywidualnie wypracowane zasady. Z punktu widzenia efektywności oddziaływań wychowawczych i edukacyjnych ważny jest nasuwający się z tych rozważań postulat zintegrowanego, całościowego i systemowego podejścia, które w praktyce może opierać się na wspólnie opracowanych wytycznych bądź porozumieniach wskazujących chociażby sposób organizacji oraz harmonogram realizowania tego typu zajęć wśród uczniów.

Konkludując, warto przytoczyć wyniki badań przeprowadzonych w latach 2011-2013 przez pracowników Katedry Bezpieczeństwa i Edukacji Obywatelskiej Uniwersytetu Pedagogicznego im. KEN w Krakowie, z których wynika, że uczniowie gimnazjów oraz szkół ponadgimnazjalnych dostrzegają — jako mankament edukacji dla bezpieczeństwa w szkole - nieuwzględnienie tematów lekcyjnych z bezpieczeństwa osobistego ${ }^{24}$. Wychodząc naprzeciw oczekiwaniom odbiorców edukacji dla bezpieczeństwa w szkole, należy diagnozować potrzeby w tym zakresie i dążyć do włączenia ich w pracę dydaktyczno-wychowawczą.

\section{Bibliografia}

Andrzejewska A., Bednarek J., Ćmiel S., Człowiek w świecie rzeczywistym i wirtualnym: wybrane patologie społeczno-wychowawcze w cyberprzestrzeni, Józefów 2013.

Cielecki T., Prewencja kryminalna. Studium z profilaktyki kryminologicznej, Opole 2004.

Czubaj A., Miejsce jednostki we współczesnym pojmowaniu bezpieczeństwa, „De Securitate et Defensione. O Bezpieczeństwie i Obronności” 1 (2), 2016, s. 65.

Czupryński A., Bezpieczeństwo w ujęciu teoretycznym, [w:] Bezpieczeństwo: teoria, badania, praktyka, red. A. Czupryński, B. Wiśniewski, J. Zboina, Józefów 2015.

Górka M., Cyberbezpieczeństwo dzieci i młodzieży: realny i wirtualny problem polityki bezpieczeństwa, Warszawa 2017.

Hoffman T., Wybrane aspekty cyberbezpieczeństwa w Polsce, Poznań 2018.

Hołyst B., Pojęcie i zakres profilaktyki kryminalistycznej, [w:] Kryminalistyka, red. B. Hołyst, Warszawa 2000.

Koziej S., Bezpieczeństwo: istota, podstawowe kategorie i historyczna ewolucja, „Bezpieczeństwo Narodowe" II-2011, nr 18.

Kwiasowski Z., Znaczenie edukacji dla bezpieczeństwa w wychowaniu obywatelskim, [w:] Edukacja dla bezpieczeństwa. Teoria i praktyka, red. A. Skrabacz, L. Kanarski, Warszawa 2014.

${ }^{24}$ Ibidem, s. 86.

Forum Socjologiczne 10, 2020

(C) for this edition by CNS 
Rosa R., Edukacja do bezpieczeństwa i pokoju w obliczu wyzwań XXI wieku, cz. 1, Filozoficzne i teoretyczne aspekty bezpieczeństwa i pokoju, Siedlce 2001.

Rywczyńska A., Reputacja online, [w:] Bezpieczeństwo dzieci online. Kompendium dla rodziców i profesjonalistów, red. A. Wrzesień-Gandolfo, Warszawa 2015, s. 84.

Sarzała D., Jędrzejko M.Z., Cyberprzemoc rówieśnicza - analiza problemu i destruktywnego wymiaru zjawiska, [w:] Cyfrowe dzieci. Zjawisko, uwarunkowania, kluczowe problemy, red. S. Bębas et al., Warszawa-Milanówek 2017.

Sikora-Wojtarowicz K., Edukacja dla bezpieczeństwa w polskiej szkole, „Rocznik Bezpieczeństwa Międzynarodowego" 11, 2017, nr 1, s. 116.

Sikorski B., Przygotowanie dzieci i młodzieży do bezpiecznego działania i współdziałania $w$ środowisku naturalnym, [w:] Przygotowanie dzieci i młodzieży do działania w sytuacjach zagrożenia zdrowia i życia, red. M. Cieślarczyk et al., Siedlce 2008.

Tyburska A., Profilaktyka uzależnień wobec zjawiska zażywania narkotyków i dopalaczy przez uczniów szkót średnich, 2018.

Wiśniewski B., Bezpieczeństwo w teorii i badaniach naukowych, Szczytno 2011.

Wojtasik Ł., Cyberprzemoc, [w:] Bezpieczeństwo dzieci online. Kompendium dla rodziców i profesjonalistów, red. A. Wrzesień-Gandolfo, Warszawa 2015.

Wojtasik Ł., Przemoc rówieśnicza a media elektroniczne, „Dziecko Krzywdzone. Teoria, badania, praktyka" 8 (1), 2009, s. 79.

\section{Akty prawne}

Ustawa z dnia 6 kwietnia 1990 r. o Policji (Dz.U. 1990 Nr 30, poz. 179 z późn. zm.).

Rozporządzenie Ministra Edukacji Narodowej z dnia 14 lutego 2017 r. w sprawie podstawy programowej wychowania przedszkolnego oraz podstawy programowej kształcenia ogólnego dla szkoły podstawowej, w tym dla uczniów z niepełnosprawnością intelektualną w stopniu umiarkowanym lub znacznym, kształcenia ogólnego dla branżowej szkoły I stopnia, kształcenia ogólnego dla szkoły specjalnej przysposabiającej do pracy oraz kształcenia ogólnego dla szkoły policealnej (Dz.U. z 2017 r. poz. 356).

\section{Źródła internetowe}

https://www.saferinternet.pl/images/stories/pdf/raport-eu-net-adb-pl-final.pdf. https://akademia.nask.pl/publikacje/Raport_z_badania_Nastolatki_3_0.pdf. http://www.antyterroryzm.gov.pl/CAT/antyterroryzm/poradniki/555,Poradniki.html.

\section{Diagnosis of educational needs in the field of personal safety in the perception of primary school students on the example of a district town}

\section{Abstract}

This paper presents the results of surveys aimed at identifying the needs and expectations of primary and junior high school students in relation to education for safety. When starting the research, the starting point was the statement that in order to effectively influence the behavior of young people in the field of safe behaviors, analyzes of threats characteristic for the region should be made, as well as diagnose the needs of the recipients themselves. The research covered a group of students 
from three schools located in Garwolin - one of the poviat cities in the Mazowieckie voivodship. Their goal was to define the educational expectations of young people in terms of personal security, limited to threats related to crime and social pathologies, which can be the basis for implementation of issues indicated by respondents in the activities of schools and institutions implementing security tasks in the region.

Keywords: education for safety, youth, criminality, social pathologies 